\title{
Demographic characteristics of an Antarctic plunderfish, Harpagifer bispinis antarcticus
}

\author{
Robert A. Daniels \\ New York State Museum, Biological Survey, Room 3132 CEC Albany, New York 12230, USA
}

\begin{abstract}
Harpagifer bispinis antarcticus Nybelin is demonstrated to be a relatively long-lived, slow-growing fish inhabiting shallow-water embayments on the Antarctic Peninsula. Age of 153 fishes taken between March and December, 1975 in Arthur Harbor, Anvers Island, was determined from otoliths. Growth rates were estimated from annuli back-calculation and using a Brody-von Bertalanffy model. Nine yr old fish were collected; annual growth increments ranged between 4 and $10 \mathrm{~mm}$ for both sexes. Growth curves of the Arthur Harbor population were similar between the sexes but differed from those of a population in Paradise Harbor. Survivorship for males and females was high, approximately $75 \%$; instantaneous mortality averaged 0.25 for females and 0.22 for males. Population structure appeared stable through the sample period; recruitment of $3 \mathrm{yr}$ old fish was most common in late autumn-early winter. Formation of the annulus occurs during the austral winter, at the same time these fish spawn, and may be associated with this event rather than decreased feeding or activity.
\end{abstract}

\section{INTRODUCTION}

Studies on the demographic characteristics of fish populations provide information necessary for practical management plans and are important to understanding the life history of fishes. Populations of Antarctic fishes, with exceptions (e.g. Everson, 1970a; Chojnacki and Palczewski, 1981; Kock, 1981; Duhamel, 1982), have not been actively studied. Age and growth of several species have been reported (e. g. Olsen, 1954, 1955; Wohlschlag, 1961; 1962; Hureau, 1966, 1970; Tomo and Cordero Funes, 1972; Shust and Pinskaya, 1978; Hureau and Ozouf-Costaz, 1980) but few studies were limited to one population and fewer were designed to monitor the population over several seasons. Yet it is this type of study that is increasingly needed as commercial exploitation of Antarctic fishes and invertebrates begins (FAO Fisheries Department, 1977; Everson, 1978; Slosarczyk and Wysokinski, 1980).

Harpagifer bispinis antarcticus is an ideal fish for population level studies for several reasons. The shallow-water, rubble-bottom habitats in which it is normally found are accessible throughout the year. This is particularly true for the population in Arthur Harbor $\left(64^{\circ} 46^{\prime} \mathrm{S}, 64^{\circ} 04^{\prime} \mathrm{W}\right)$, Antarctic Peninsula detailed here. Traditional sampling methods - otter trawls and traps - can be abandoned in favor of actual observations and collecting by divers. The demersal populations are discrete and their boundaries sharply delineated so that interpopulation comparisons can be made. For example, I compare some characteristics of the Arthur Harbor population to that of Paradise Harbor $\left(64^{\circ} 51^{\prime} \mathrm{S}\right.$, $62^{\circ} 54^{\prime} \mathrm{W}$ ) described by Tomo and Cordero Funes (1972). Finally, other aspects of the biology of $H$. $b$. antarcticus have been examined (Moreno, 1971; Daniels, 1978, 1979, 1982; Duarte and Moreno, 1981; Wyanski and Targett, 1981) and its role in shallowwater fish associations is at least partially understood (Targett, 1981). It is not likely that $H$. b. antarcticus will ever become commercially important, and this point too makes it an ideal study animal since it can serve in comparative studies as an unexploited species. Lastly, populations of $H$. b. antarcticus will become effective monitors of activity along the Antarctic Peninsula and surrounding islands. It is the shallow-water, nearshore habitats, populated by $H$. b. antarcticus, that will receive the brunt of man's activities. If initial data are available, changes in the structure of $H$. b. antarcticus populations will document future activity. 


\section{METHODS AND PRELIMINARY FINDINGS}

Specimens were taken from Arthur Harbor, Anvers Island, Antarctic Peninsula from March to December, 1975. Additional collections were made at Paradise Harbor, Argentine Islands $\left(65^{\circ} 15^{\prime} \mathrm{S}, 64^{\circ} 16^{\prime} \mathrm{N}\right)$ and Port Lockroy $\left(65^{\circ} 49^{\prime} \mathrm{S}, 63^{\circ} 30^{\prime} \mathrm{W}\right)$ in December, 1975. These sites (Fig. 1), described in greater detail in Daniels

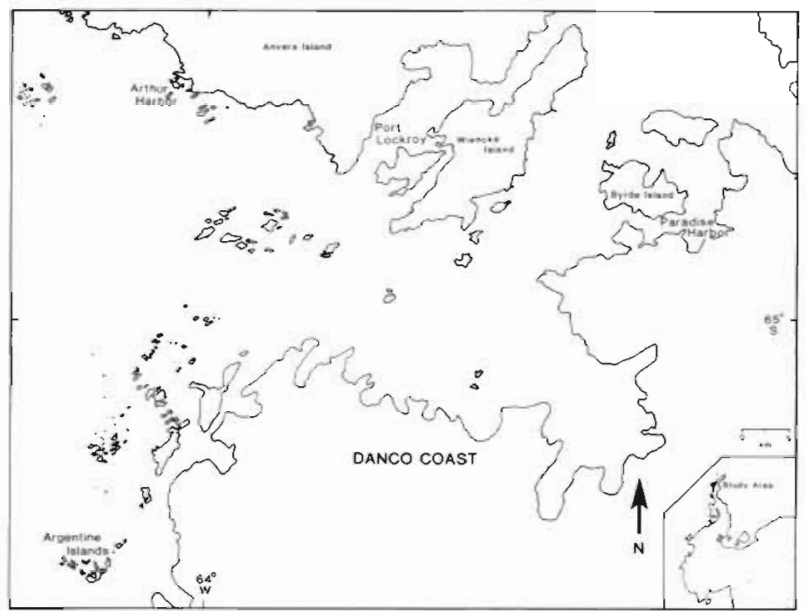

Fig. 1. Sample sites, within $75 \mathrm{~km}$ of each other in the midlatitudes of the west coast of the Antarctic Peninsula, on or adjacent to the Palmer Archipelago

(1982) and Daniels and Lipps (1982), are at the southern edge of the known range of Harpagifer $b$. antarcticus. The areas sampled were shallow-water, cobblesubstrate coves. Slopes were gentle and $H$. $b$, antarcticus was taken at depths from $1 \mathrm{~m}$ (The Buttons, Argentine Is) to $17 \mathrm{~m}$ (Delaca Island, Arthur Harbor). They were found only under rocks, or on rare occasions, algal fronds.

The fishes were taken by divers. A suitable site was selected, then 2 divers descended and independently turned rocks until a fish was observed. The fish was then picked up by hand and retained. When 20 to 25 fish were taken, collecting stopped, thus no size- or sex-related bias should be present in the samples. Specimens were fixed and preserved in $4 \%$ buffered formaldehyde solution at the completion of the dive and sagittae were removed within $2 \mathrm{~h}$ of fixation. These otoliths were stored in vials in glycerine.

All fishes were measured (standard length [SL] in $\mathrm{mm}$ ), weighed (less gonads, liver and intestinal tract) and otoliths from 153 fishes collected between March and December from Arthur Harbor were read. The presence of large parasites was noted. The otoliths were placed in a glycerine bath under a dissecting scope under reflected light and measured with an ocular micrometer. The radius and distance from the focus to the outer edge of the opaque band were measured. I read the otoliths twice, in 1975 and 1981 and they were read independently by a second individual. Average percent error (Beamish and Fournier, 1981) for the 3 readings ranged from $4.3 \%$ in age Group 3 to 25.5 in Group 9. The age used in the analysis was that age read at least twice. Methods to enhance the annuli on the otolith, discussed by Everson (1980) were not deemed necessary.

The difference between the radius and the distance from the focus and the edge of the last annulus was compared by month to determine when the annulus is set. The mean difference is greatest in June, drops to its lowest in September, and rises in the monthly samples taken between October and May. A difference exists between the June $(\bar{x}=0.24 \mathrm{~mm}, \mathrm{n}=19)$ and September $(\overline{\mathrm{x}}=0.16 \mathrm{~mm}, \mathrm{n}=23$ ) samples (t-test, $\alpha=0.05$ ), but not between any of the other seasonal samples (December, $\overline{\mathrm{x}}=0.20 \mathrm{~mm}, \mathrm{n}=22 ;$ March, $\overline{\mathrm{x}}=0.22$, $\mathbf{n}=12$ ) at a similar level of significance. Thus, the rings which are visible appear to be annuli; the annulus is set between June and September.

With this established, further analysis of the age structure was warranted. The sample was divided by sex and SL was regressed on radius. The correlation of each regression was significant $(p=0.01)$. The regression lines were compared (Neter and Wasserman, $1974)$ and found similar $\left(F=1.67<F_{(0.05)}\right.$, df $\left.=2,149\right)$.

Length at each age $\left(\mathrm{L}_{\mathrm{i}}\right)$ was calculated from the focus-annulus measurement $\left(S_{i}\right)$ using the Lee method

$$
\mathrm{L}_{\mathrm{i}}=\mathrm{a}+\left(\frac{\hat{\mathrm{L}}_{\mathrm{c}}-\mathrm{a}}{\hat{\mathrm{S}}_{\mathrm{c}}}\right) \mathrm{S}_{\mathrm{i}}
$$

where $\hat{S}_{C}=$ radius; $\hat{L}_{c}=$ length of the fish at capture; $\mathrm{a}=\mathrm{y}$-intercept of the SL-radius regression (Carlander, 1981). Only data from the first seven year classes were used since precision in reading otoliths drops in the older age groups.

Since Tomo and Cordero Funes (1972) used total length (TL) in their study, TL and SL were measured on 50 specimens (New York State Museum 6946). The regression, $\mathrm{SL}=1.23+0.827$ (TL) $(\mathrm{r}=0.98$, significant at $\mathrm{p}=0.01$ ), was used to convert TL measurements.

Theoretical growth curves for both sexes in both the Arthur Harbor and Paradise Harbor (Tomo and Cordero Funes, 1972) populations were calculated using von Bertalanffy's equation (Ricker, 1975):

$$
\mathrm{l}_{\mathrm{t}}=\mathrm{L}_{\infty}\left(1-\mathrm{e}^{-\mathrm{K}\left(\mathrm{t}-\mathrm{t}_{\mathrm{o}}\right)}\right)
$$

where $\mathrm{L}_{\infty}=$ theoretical maximum age; $l_{t}=$ length at time $t ; K=$ constant indicating the rate of change in length increments (Brody growth co-efficient); $t_{o}=$ time the fish would have been $0 \mathrm{~mm}$ had its growth been consistent with that described by the equation. The constants, $L_{\infty}, K$ and $t_{0}$, were computed using methods in Ricker (1975). Growth curves between the 
sexes in each population and between populations were compared using the method suggested by Kappenman (1981) as modified in Boehlert and Kappenman (1980). Two-way comparisons were made between alternative models, designated $M_{n}$, using mean for SL for each age group weighted by the sample size. In both populations, male and female growth curves were compared; then, a between-population comparison was made. For each $M_{n_{1}}$ a sum of squares deviation, $D_{n}$, was determined; the model with the lower $D_{n}$ is favored.

Survivorship (s) and instantaneous mortality (z) were calculated for the Arthur Harbor population using the methods of Heincke and Robson and Chapman (Ricker, 1975). Only fish aged from otoliths were used in these calculations. There are 2 assumptions which need satisfaction when computing survivorship-mortality (Ricker, 1975). The collecting technique should assure a random sample of the population, which is met in this study. The second, that mortality and recruitment are constant, is difficult to assess. A plot of ln(year class abundance) against age results in a straight line after age $4\left(\mathrm{r}-0.84 ; \mathrm{F}=0.4>\mathrm{F}_{1,4}\right.$; $\mathrm{P}=0.05$ ), which indicates a steady mortality rate. All year classes $>3$ are represented in the sample; since the data were collected during one season it appears that recruitment occurs annually. The survivorship calculations were repeated for the data of Tomo and Cordero Funes (1972). This is done for comparison only and no test of the assumptions is attempted.

Age structure is examined by percentage composition of each sample. Given the sample sizes $(n<30)$, only trends can be identified. The number of fish caught per minute provides an estimate of relative abundance which is used to compare the December samples from 4 collecting sites. Again, due to the small sample sizes, and lack of replication, this estimate is crude, but does indicate trends.

\section{RESULTS}

Use of otoliths in ageing Harpagifer $b$. antarcticus has not been reported. I found them to be a good record of age and found that they provided consistent results. The hyaline zone is readily visible in the autumn samples and continues to edge most otoliths in samples collected through the winter. An opaque border becomes visible in most otoliths collected in September, but opaque borders are visible in otoliths as early as July.

In both Arthur Harbor and Paradise Harbor, 9 yr old fish were collected; SL ranged between 85 and $95 \mathrm{~mm}$. Growth differed between the populations. Tomo and Cordero Funes (1972) found no difference in growth
Table 1. Harpagifer bispinis antarcticus. Von Bertalanffy equations and weighted sums of squares of deviations, $D_{n}$, for the alternative models of growth in Arthur Harbor and Paradise Harbor populations. Only data through year 7 is used. Altemative models, $M_{n}$, are that the 2 curves are similar, $M_{1}$, or that they differ, $M_{2}$. The model with the lower $D_{n}$ value is favored

Equations

Arthur Harbor

Female

Male

$l_{t}=109\left(l-e^{-0.13(t+1.7)}\right)$
$l_{t}=101\left(l-e^{-0.15(t+1.0)}\right)$

Paradise Harbor Female

Male

$l_{t}=104\left(1-e^{-0.26(1+0.7)}\right)$

$l_{t}=107\left(1-e^{-0.24 t}+1.0\right)$

Comparisons

Sex

$\mathrm{D}_{1}$

$\mathrm{D}_{2}$

Arthur Harbor Paradise Harbor

Geographic

$D_{1}$
$D_{2}$

$\begin{array}{rr}42 & 226 \\ 1050 & 2430\end{array}$

Female
2404

1652

Male

2510

1828

between males and females in Paradise Harbor (Table 1). The von Bertalanffy growth curve for this population shows relatively rapid growth during the early years and a leveling during the last growing seasons (recalculated in terms of SL and shown in Fig. 2). This differs from the Arthur Harbor population.

In Arthur Harbor, growth is similar between males and females (Tables 1 and 2). Based on back-calculations individuals in the sample reached $\sim 30 \mathrm{~mm}$ in their first growing season and then added an addi-

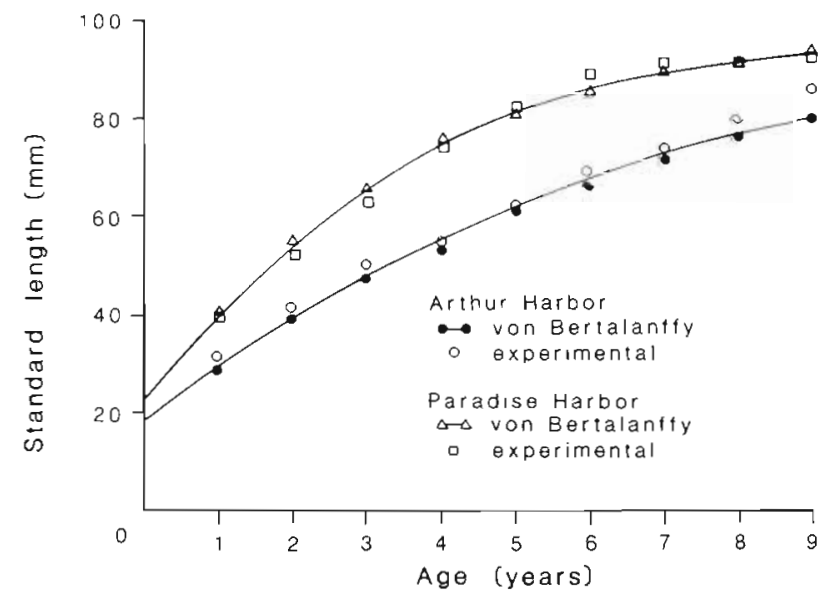

Fig. 2. Harpagifer bispinis antarcticus. Von Bertalanffy growth curves for populations at Arthur Harbor and Paradise Harbor. Symbols represent mean standard lengths calculated from specimens collected in Arthur Harbor in 1975 and from tables of Tomo and Cordero Funes (1972) from Paradise Harbor 
Table 2. Harpagifer bispinis antarcticus. Mean and back-calculated standard lengths (mm) and $95 \%$ confidence intervals (in parentheses), at successive annuli for individuals collected in Arthur Harbor, Antarctic Peninsula, 1975

\begin{tabular}{|c|c|c|c|c|c|c|c|c|c|c|}
\hline $\begin{array}{l}\text { Age } \\
\text { group }\end{array}$ & $\mathrm{n}$ & 1 & 2 & 3 & 4 & 5 & 6 & 7 & 8 & 9 \\
\hline 3 & 9 & $34.5(1.81)$ & $44.4(1.80)$ & $50.6(1.34)$ & & & & & & \\
\hline 4 & 32 & $32.9(1.00)$ & $42.6(1.20)$ & $51.5(1.13)$ & $58.5(0.87)$ & & & & & \\
\hline 5 & 27 & $31.8(0.99)$ & $41.6(0.93)$ & $50.8(0.97)$ & $58.1(1.02)$ & $64.4(0.95)$ & & & & \\
\hline 6 & 27 & $31.5(0.93)$ & $41.2(1.05)$ & $49.3(1.05)$ & $56.5(1.00)$ & $63.3(0.83)$ & 69.2 & & & \\
\hline 7 & 27 & $31.3(1.05)$ & $40.6(0.97)$ & $48.5(0.93)$ & $55.1(1.04)$ & $61.6(1.27)$ & $67.1(1.06)$ & $72.6(0.93)$ & & \\
\hline 8 & 21 & $32.9(1.35)$ & $42.1(1.43)$ & $49.8(1.34)$ & $57.3(1.60)$ & $63.5(1.61)$ & $69.7(1.34)$ & $74.2(1.21)$ & $78.9(1.18)$ & \\
\hline 9 & 10 & $33.3(1.68)$ & $42.9(1.47)$ & $52.8(2.16)$ & $60.6(2.11)$ & $67.2(2.49)$ & $73.1(2.61)$ & 78.0 & $83.3(1.95)$ & $87.8(2.28)$ \\
\hline Total & 153 & & & & & & & & & \\
\hline $\begin{array}{l}\text { Weighted } \\
\text { mean }\end{array}$ & & 32.3 & 41.9 & 50.2 & 57.4 & 63.5 & 69.1 & 74.1 & 80.3 & 87.8 \\
\hline $\begin{array}{l}\text { Growth } \\
\text { increment }\end{array}$ & & 9. & 6 & .3 & .2 & .1 & 5.6 & 5 & 7.5 & \\
\hline
\end{tabular}

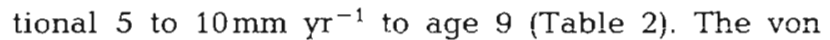
Bertalanffy curve approximates year-class mean lengths from back-calculations and shows a steady, gradual, almost linear increase in length through age 9 (Fig. 2).

The relationship between SL and weight (W) in the Arthur Harbor population fits well $\mathrm{W}(\mathrm{g})=\mathrm{a}(\mathrm{SL}[\mathrm{mm}])^{\mathrm{b}}$, where $a$ and $b$ are constants. The values $a$ and $b$ were derived from a $\log _{10}$ transformation and least squares fit and determined to be -11.56 and 3.26 respectively for females and -11.39 and 3.21 respectively for males. No sex-related difference was detected in this relationship $\left(F=1.15<F_{(.05,2,149)}=3.0\right)$ (Fig. 3).

Survivorship rates ranged from 0.65 to 0.79 and were

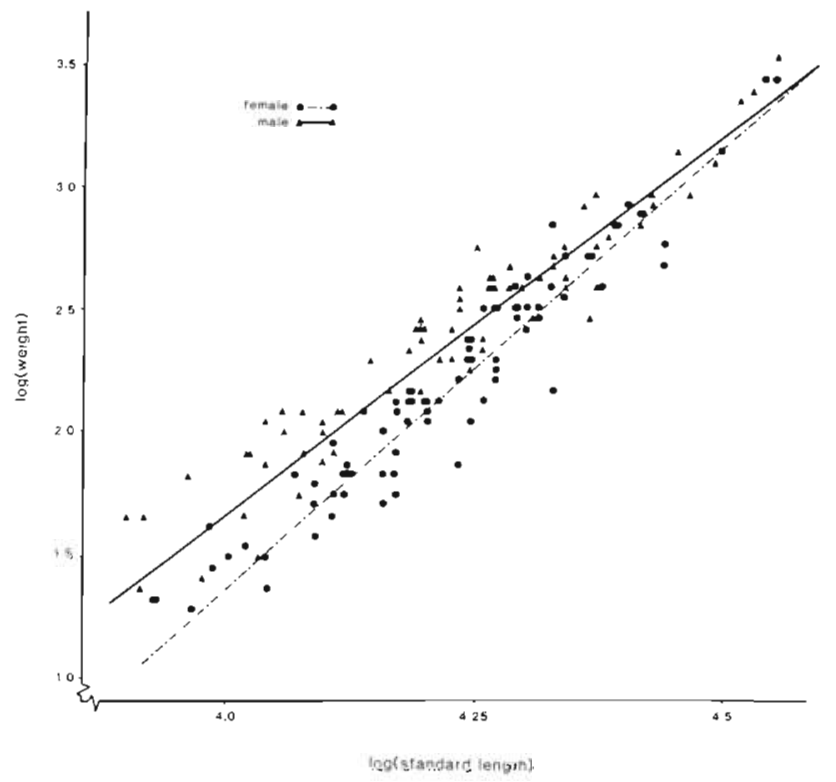

Fig. 3. Harpagifer bispinis antarcticus, Length-weight relationships from male and female specimens taken in Arthur Harbor, Antarctic Peninsula, 1975
Table 3. Harpagifer bispinis antarcticus. Survivorship (S) and instantaneous mortality (Z) rates for 2 populations of Antarctic Peninsula. Data for Arthur Harbor population presented in this report; that for Paradise Harbor from Tomo and Cordero Funes (1972)

\begin{tabular}{|lccc|}
\hline & $\begin{array}{c}\text { Survivorship (S) } \\
\text { Heincke }\end{array}$ & $\begin{array}{c}\text { Robson and } \\
\text { Chapman }\end{array}$ & $\begin{array}{c}\text { Instantaneous } \\
\text { mortality (Z) }\end{array}$ \\
\hline $\begin{array}{l}\text { Arthur Harbor } \\
\text { Female }\end{array}$ & 0.79 & 0.73 & 0.25 \\
$\quad \begin{array}{l}\text { Male } \\
\text { Paradise Harbor }\end{array}$ & 0.79 & 0.76 & 0.22 \\
$\quad \begin{array}{l}\text { Female } \\
\text { Male }\end{array}$ & 0.74 & 0.79 & - \\
\hline
\end{tabular}

consistent between sexes and populations (Table 3). Also, both methods used, those of Heincke and Robson and Chapman, yielded similar results. Instantaneous mortality for individual year classes in the Arthur Harbor population ranged from 0 to 0.88 ; mean rates were similar between sexes. Meaningful results for the Paradise Harbor population could not be calculated. Among 171 specimens examined from Arthur Harbor, I found parasites, usually nematodes, in 18 specimens.

Recruitment into the demersal Arthur Harbor population appears to occur at $3 \mathrm{yr}$. Tomo and Cordero Funes (1972) report specimens from age Groups 1 and 2 and I collected 2 yr fish at Port Lockroy. The middle age groups (5 to 7) are dominant in the monthly samples and in the 4 December samples (Table 4). The relative abundance of Harpagifer $b$. antarcticus varied among the sites. They were quite densely packed in Paradise Harbor and relatively rare at Port Lockroy, It is difficult to explain the differences in abundance based on habitat; all 4 sites were cobble-bottom coves with scattered algae and gently sloping bottoms. All 
Table 4. Harpagifer bispinis antarcticus. Percentage composition by year class of the Arthur Harbor population, June-December, 1975. During December, 1975, samples from Paradise Harbor, Port Lockroy and Argentine Islands are compared. An effort estimate (no. of fish/min collecting time) is provided for December catches

\begin{tabular}{|c|c|c|c|c|c|c|c|c|c|c|}
\hline \multirow[t]{2}{*}{$\begin{array}{l}\text { Age- } \\
\text { group }\end{array}$} & \multirow[t]{2}{*}{ Jun } & \multirow[t]{2}{*}{ Jul } & Aug & Sep & Oct & \multirow[t]{2}{*}{$\begin{array}{l}\text { Month } \\
\text { Nov }\end{array}$} & \multicolumn{4}{|c|}{ Dec } \\
\hline & & & \multicolumn{3}{|c|}{ Arthur Harbor } & & $\begin{array}{l}\text { Arthur } \\
\text { Harbor }\end{array}$ & $\begin{array}{c}\text { Paradise } \\
\text { Harbor }\end{array}$ & $\begin{array}{c}\text { Port } \\
\text { Lockroy }\end{array}$ & $\begin{array}{l}\text { Argentine } \\
\text { Islands }\end{array}$ \\
\hline 2 & 0 & 0 & 0 & 0 & 0 & 0 & 0 & 0 & 9 & 0 \\
\hline 3 & 5 & 5 & 0 & 4 & 4 & 4 & 4 & 4 & 13 & 0 \\
\hline 4 & 38 & 0 & 7 & 0 & 12 & 22 & 4 & 20 & 0 & 5 \\
\hline 5 & 47 & 5 & 19 & 8 & 28 & 52 & 29 & 32 & 13 & 20 \\
\hline 6 & 5 & 32 & 27 & 36 & 36 & 18 & 25 & 20 & 30 & 50 \\
\hline 7 & 0 & 48 & 23 & 20 & 8 & 0 & 25 & 12 & 22 & 20 \\
\hline 8 & 5 & 5 & 12 & 16 & 8 & 4 & 9 & 8 & 13 & 5 \\
\hline 9 & 0 & 5 & 12 & 16 & 4 & 0 & 4 & 4 & 0 & 0 \\
\hline $\mathrm{n}$ & 19 & 19 & 26 & 25 & 25 & 23 & 28 & 25 & 23 & 20 \\
\hline Effort & & & & & & & 0.93 & 1.67 & 0.70 & 1.00 \\
\hline
\end{tabular}

collecting dives were shallow-water, $<12 \mathrm{~m}$, and all samples were taken within 1 wk of each other. All sites were near small human populations except Port Lockroy, where the station had been closed for several years.

\section{DISCUSSION}

Results reported here and elsewhere (Tomo and Cordero Funes, 1972; Everson, 1968) show Harpagifer b. antarcticus to be a slow-growing, relatively long-lived fish. This is particularly interesting since it is a small, near-shore, demersal fish, with few specimens reaching 95 mm SL (Lönnberg, 1905; Regan, 1914; Norman, 1938; Tomo and Cordero Funes, 1972; Wyanski and Targett, 1981). It and Notothenia neglecta are the most commonly encountered shallow-water fishes along the Antarctic Peninsula and $H$. b. antarcticus is the only fish commonly taken from tide pools (Duarte and Moreno, 1981; Wyanski and Targett, 1981). Considering the constantly changing nature of these environments (Kaufmann, 1977), animals with typically Kselected (Pianka, 1970) characteristics are not necessarily expected. In addition to slow growth, long life and high survivorship, $H$. b. antarcticus is iteroparous and devotes a great deal of time to parental care (Daniels, 1978, 1979); it is specialized in feeding (Duarte and Moreno, 1981; Daniels, 1982) and habitat choice (Daniels and Lipps, 1982). More importantly, it is becoming increasingly obvious as age-growth studies on Antarctic fishes proliferate that slow growth - long life is the norm (Table 5), and this must be considered when plans for a sustained Antarctic fishery are developed. The advantages of a fishery based on the capture of fishes that take 10 to $20 \mathrm{yr}$ to

Table 5. Ages and maximum lengths (in standard [SL] or total length [TL]) of several Antarctic fishes

\begin{tabular}{|c|c|c|c|c|c|}
\hline Species & Collecting site & $\begin{array}{l}\text { Sample } \\
\text { size }\end{array}$ & $\begin{array}{l}\text { Maximum } \\
\text { recorded } \\
\text { age }(y r)\end{array}$ & $\begin{array}{l}\text { Maximum } \\
\text { recorded } \\
\text { length (mm) }\end{array}$ & Source \\
\hline Notothenia neglecta & South Orkney Is. & 205 & 18 & $454 \mathrm{SL}$ & Everson (1970) \\
\hline \multirow[t]{4}{*}{ N. rossii marmorata } & South Georgia & -2000 & 13 & $800-900 \mathrm{TL}$ & Olsen (1954) \\
\hline & South Georgia & 132 & 15 & $790 ?$ & Freytag (1980) \\
\hline & South Shetland Is. & 484 & 19 & $810 ?$ & Freytag $(1980)$ \\
\hline & 'Southern Ocean' & 470 & 14 & $752 \mathrm{TL}$ & Shust and Pinskaya (1978) \\
\hline N. gibberifrons & 'Southern Ocean' & 237 & 14 & $505 \mathrm{TL}$ & Shust and Pinskaya (1978) \\
\hline N. kempi & 'Southern Ocean' & 58 & 14 & $430 \mathrm{TL}$ & Shust and Pinskaya (1978) \\
\hline N. larseni & 'Southern Ocean' & 32 & 9 & $230 \mathrm{TL}$ & Shust and Pinskaya (1978) \\
\hline N. squamifrons atlantica & 'Southern Ocean' & 99 & 14 & $520 \mathrm{TL}$ & Shust and Pinskaya (1978) \\
\hline Trematomus hansoni & 'Southern Ocean' & 72 & 9 & $395 \mathrm{TL}$ & Shust and Pinskaya (1978) \\
\hline T. bernacchii & McMurdo Sound & 178 & 9 & $270 \mathrm{TL}$ & Wohlschlag (1961) \\
\hline Dissostichus elegenoides & $\begin{array}{l}\text { Kerguelen Is. } \\
\text { Crozet Is. }\end{array}$ & 69 & 21 & $845 \mathrm{SL}$ & Hureau and Ozouf-Costaz (1980) \\
\hline \multirow[t]{2}{*}{ Harpagifer bispinis } & Paradise Harbor & 123 & 9 & $94 \mathrm{SL}$ & Tomo and Cordero Funes (1972) \\
\hline & Arthur Harbor & 153 & 9 & $95 \mathrm{SL}$ & This study \\
\hline Chaenichthys rhinoceratus & Kerguelen Is. & 34 & 12 & $475 \mathrm{SL}$ & Hureau (1966) \\
\hline
\end{tabular}


attain maximum size and that may require in excess of 7 to $14 \mathrm{yI}$ to reach maturity (e.g. Everson, 1970b) must be carefully examined. The absolute abundance of the organisms, the effect fishing gear will have on the nesting grounds of demersal fishes (Daniels, 1978; Moreno, 1980) and the effect a general increase in activity will have on the fish stocks and the abundance of their prey are only a few considerations; none have been adequately explored although there is some indication that fishing does affect the mean length of the stock (Skora, 1980; Duhamel, 1982).

It is difficult to explain the absence of first and second age group fish in Arthur Harbor when they were readily taken in Paradise Harbor (Tomo and Cordero Funes, 1972). It is not likely that I overlooked them at the sample sites; fish and invertebrates smaller than $30 \mathrm{~mm}$ were taken regularly. It is possible that they inhabit a different microhabit entirely, tidepools, for example, as suggested by the coliecting resuits of Duarte and Moreno (1981), Targett (1981) and Wyanski and Targett (1981). Everson (1968) reported that Harpagifer $b$. antarcticus settle out in late autumn at 24 to $28 \mathrm{~mm}$ TL, a figure approximating the back-calculated length for $1 \mathrm{yr}$ old individuals in this study. Tidepools are rare in Arthur Harbor; the few that exist were never sampled.

The difference in growth rates between Arthur Harbor and Paradise Harbor populations also merits comment. The small sample sizes in both this study and that of Tomo and Cordero Funes (1972) may accent errors in interpreting ages. Larger samples are needed in future studies, but the results of these studies cannot be dismissed because of sample size alone. Paradise Harbor fish appear to grow faster and larger than those in Arthur Harbor; Harpagifer b. antarctius is also more abundant in Paradise Harbor. Several explanations are possible, for example: Arthur Harbor may be marginal habitat or H. b. antarcticus may be establishing itself in Arthur Harbor or the opposite, it may be declining. Long-term studies would be useful.

The growing season, based on the opaque-hyaline borders on the otolith, runs from late winter to late summer. This coincides with other findings (Everson, $1970 a_{i}$ North et al., 1980). The period of slow growth corresponds to the spawning season and it is this funnelling of energy into reproductive tissue and activity that may account for the depressed somatic growth rate. Feeding occurs throughout the year in most fishes examined from the Antarctic Peninsula (Marshall, 1965; Daniels, 1982) and activity does not appear to decrease in winter months (Daniels, 1978), thus it is possible that the annuli represent spawning activity.

Acknowledgements. I thank fellow divers, D. Laine and W. Showers, and support personnel at PaImer Station, Winter,
1975, especially W. Lokey. I also appreciate comments and advice from $\mathrm{H}$. H. DeWitt. This research was partially funded by NSF grants GV-31162 and OPP74-12139 to J. H. Lipps. Published as New York State Museum contribution No. 404.

\section{LTTERATURE CITED}

Beamish, R. J., Fournier, D. A. (1981). A method for comparing the precision of a set of age determinations. Can. J. Fish. Aquat. Sci. 38: 982-983

Boehlert, G. W., Kappenman, R. F. (1980). Latitudinal growth variation in the genus Sebastes from the northeast Pacific Ocean. Mar. Ecol. Prog. Ser. 3: 1-10

Carlander, K. D. (1981). Caution on the use of the regression method of back-calculating lengths from scale measurements. Fisheries 6: 2-4

Chojnacki, J., Palczewski, P. (1981). Age and growth rate of Pseudochaenichtys georgianus Norman, 1937 (Family Chaenichthyidae) of the South Georgia region. Pol. Polar Res. 2: 145-57

Daniels, R. A. (1978). Nesting behaviour of Harpagifer bispinis in Arthur Harbour, Antarctic Peninsula. J. Fish. Biol. 12: $465-474$

Daniels, R. A. (1979). Nest guard replacement in the Antarctic fish Harpagifer bispinis; possible altruistic behavior. Science, N. Y. 205: 831-833

Daniels, R. A. (1982). Feeding ecology of some fishes of the Antarctic Peninsula. Fish. Bull. U. S. 80: 575-88

Daniels, R. A., Lipps, J. H. (1982). Distribution and ecology of fishes of the Antarctic Peninsula. J. Biogeogr. 9: 1-9

Duarte, D. W., Moreno, C. A. (1981). The specialized diet of Harpagifer bispinis: its effect on the diversity of Antarctic intertidal amphipods. Hydrobiologia 80: 241-250

Duhamel, G. (1982). Biology and population dynamics of Notothenia rossii rossii from the Kerguelen Islands (Indian Sector of Southern Ocean). Polar Biol. 1: 141-51

Everson, I. (1968). Larval stages of certain Antarctic fishes. Br. Antarct. Surv. Bull. 16: 65-70

Everson, I. (1970a). The population dynamics and energy budget of Notothenia neglecta Nybelin at Signy Island, South Orkney Islands. Br. Antarct. Surv. Bull. 23: 25-50

Everson, I. (1970b). Reproduction in Notothenia neglecta Nybelin. Br. Antarct. Surv. Bull. 23: 81-92

Everson, I. (1978). Antarctic fisheries. Polar Rec. 19: 233-51

Everson, I. (ed.) (1980). Antarctic fish age determination methods. Biomass Handbk No. 8: 1-24

FAO (1977). FAO Yearbook for fishery statistics, Atlantic, Antarctic (Major Fishing Area 48). FAO, Rome. Circular No. 639: 1-17

Freytag, G. (1980). Problems in ageing Notothenia rossii marmorata. Cybium 3e série 1980 (8): 43-51

Hureau, J.-C. (1966). Biologie de Chaenichthys rhinoceratus Richardson, et problème du sang incolore des Chaenichthyidae, poissons des mers australes. Bull. Soc. Zool. France 91: 735-751

Hureau, J.-C. (1970). Biologie comparée de quelques poissons antarctiques (Nototheniidae). Bull. Inst. oceanogr. Monaco 68 (1391): 1-244

Hureau, J.-C., Ozouf Costaz, C. (1980). Age determination and growth of Dissostichus eleginoides Smitt, 1898 from Kerguelen and Crozet Islands. Cybium 3e série 1980 (8): 23-32

Kappenman, R. F. (1981). A method for growth curve comparisons. Fish. Bull. U. S. 79: 95-101

Kauffman. T. A. (1977). Seasonal changes and disturbance in 
an Antarctic benthic mud community. Ph. D. dissertation, University of California, Davis

Kock, K.-H. (1981). Fischereibiologische Untersuchungen an drei antarktischen Fischarten: Champsocephalus gunnari Lönnberg, 1905, Chaenocephalus aceratus (Lönnberg, 1906) und Pseudochaenichthys georgianus Norman, 1937 (Notothenioidei, Channichthyidae). Mitt. Inst. Seefisch. 32: $1-226$

Lönnberg, E. (1905). The fishes. Wriss. Brgebn. Schwedischen Sudpolar-Exped. 1901-1903. Vol. 5, Lief. 6

Marshall, N. B. (1964). Fish. In: Priestly, R., Adie, R. J., Robin G. de Q. (ed.) Antarctic research: a review of British scientific achievement in Antarctica. Butterworths, London, p. 206-218

Moreno, C. (1971). Somatometría y alimentación natural de Harpagifer georgianus antarcticus, Nybelin, en Bahía Fildes, Isla Rey Jorge, Antarctica. Bol. Inst. Antárct. Chile 6: $9-12$

Moreno, C. A. (1980). Observations on food and reproduction in Trematomus bernacchii (Pices: Nototheniidae) from the Palmer Archipelago. Copeia 1980: 171-173

Neter, J., Wasserman, W. (1974). Applied linear statistical models: regression, analysis of variance, and experimental design. R.D. Irwin, Inc. Homewood, Illinois

Norman, J. R. (1938). Coast fishes. Pt. 3. The Antarctic zone. 'Discovery' Rep. 18: 1-104

North, A. W., White, M. C., Burchett, M. S. (1980). Age determination in Antarctic fish. Cybium 3e série 1980 (8): 7-11

Olsen, S. (1954). South Georgian cod (Notothenia rossii marmorata) Fischer. Norsk Hvalfangsttid. 7: 373-382

Olsen, S. (1955). A contribution to the systematics and biology of chaenichthyid fishes from South George. Nytt Mag. Zool. 3: 79-93

Pianka, E. R. (1970). On r- and K-selection. Am. Nat. 104: 952-597

Regan, C. T. (1914). Fishes. British Antarctic (Terra Nova) Exped. 1910. Zoology 1: 1-54

Ricker, W. E. (1975). Computation and interpretation of Biological statistics of fish populations. Fish. Res. Bd Can. Bull. 191: 1-382

Shust, K. V., Pinskaya, I. A. (1978). Age and rate of growth of six species of notothenid fish (family Nototheniidae). J. Ichthyol. 18: 743-749

Slosarczyk, W., Wysokinski, A. (1980). Ichthyological and fishery studies of the shelf fishing grounds in the region of the Kerguelen Islands (Antarctica). Pol. Polar Res. 1: $173-190$

Skora, K. E. (1980). Changes in the composition of Notothenia gibberifrons Lönnberg population of the shelf of South Georgia in the years 1977-79. Pol. Polar Res. 1: 155-162

Targett, T. E. (1982). Trophic ecology and structure of coastal Antarctic fish communities. Mar. Ecol. Prog. Ser. 4: 243-263

Tomo, A. P., Cordero Funes, J. R. (1972). Edad y crecimiento en largo del Harpagifer bispinis antarcticus, Contrib. Inst. Antart. Argent. 96: 1-19

Wohlschlag, D. E. (1961). Growth of an Antarctic fish at freezing temperatures. Copeia 1961: 11-18

Wohlschlag, D. E. (1962). Antarctic fish growth and metabolic differences related to sex. Ecology 43: 589-597

Wyanski, D. M., Targett, T. E. (1981). Feeding biology of fishes in the endemic Antarctic Harpagiferidae. Copeia 1981: 686-693 